\title{
RDP1258, a New Rationally Designed Immunosuppressive Peptide, Prolongs Allograft Survival in Rats: Analysis of Its Mechanism of Action
}

\author{
Maria Cristina Cuturi, ' Frank Christoph,' Jacky Woo, ${ }^{2}$ \\ Suhasini Iyer, ${ }^{2}$ Sophie Brouard, ' Jean Marie Heslan, ${ }^{1}$ \\ Pascale Pignon, ${ }^{3}$ Jean-Paul Soulillou, ${ }^{1}$ and Roland Buelow ${ }^{2}$ \\ ${ }^{1}$ ITERT/INSERM U437, Nantes, France \\ ${ }^{2}$ SangStat Medical Corporation, Fremont, California, U.S.A. \\ ${ }^{3}$ SangStat Atlantique, CHU de Nantes, France \\ Accepted September 24, 1999.
}

\begin{abstract}
Peptides derived from the HLA class I heavy chain (a.a. 75-84) have been shown to modulate immune responses in vitro and in vivo in a non-allele-restricted fashion. In vivo studies in rodents have demonstrated prolonged allograft survival following peptide therapy. The immunomodulatory effect of these peptides has been correlated with peptide-mediated modulation of heme oxygenase 1 activity (HO-1). Recently, we used a rational approach for designing novel peptides with enhanced immunosuppressant activity. These peptides were also more potent inhibitors of HO-l activity in vitro. Here we evaluated one of these peptides, RDP1258, for its ability to prolong heterotopic heart graft survival in rats. The peptide mediated effect on HO-1 was analyzed in vitro and in vivo. Peptide RDP1258 was shown to inhibit rat $\mathrm{HO}-1$ in vitro in a dose-dependent fashion. However, RDP1258, like other HO-inhibitors,
\end{abstract}

when administered to rats, secondarily resulted in an up-regulation of splenic HO-1 activity. Up-regulation of HO-1 was associated with prolonged heart allograft survival $(6.6 \pm 0.6$ vs. $2 / 14>100$ days and $12 / 1416.2 \pm$ 1.7 days; $p<0.001)$. The analysis of graft infiltrating cells on day 5 after transplantation showed a significant decrease in the number of graft infiltrating cells in RDP1258-treated recipients compared to untreated ones ( 14.8 vs. $32.7 \% ; p<0.01$ ). In addition, grafts from peptide-treated animals showed significantly decreased expression of TNF- $\alpha$ mRNA and increased levels of iNOS mRNA. Our results are consistent with the recent observation that up-regulation of $\mathrm{HO}-1$ results in the inhibition of several immune effector functions. Modulation of HO-l activity may enable the development of novel immunomodulatory strategies in humans.

\section{Introduction}

The main molecular targets of the alloimmune response are the major histocompatibility complex (MHC) molecules. Over the past decade,

Address correspondence and reprint requests to: Dr. Maria Cristina Cuturi, ITERT/INSERM U437, Centre Hospitalier, Universitaire de Nantes, Hotel-Dieu, 30 boulevard Jean Monnet, 44093 Nantes Cedex 1, France. Phone: 3324008 7410; Fax: 3324008 7411; E-mail: ccuturi@nantes.inserm.fr several investigators have evaluated the use of soluble MHC molecules to modulate immune responses and allograft rejection. Synthetic peptides corresponding to various regions of MHC molecules have been shown to affect $\mathrm{T}$ cell functions in vitro. Krensky and others (1-3) showed that synthetic peptides derived from the class I heavy chain inhibited lysis by cytotoxic $\mathrm{T}$ lymphocytes (CTLs). In particular, two peptides corresponding to amino acid 75-84 of the $\alpha$ l helix 
of HLA B-2702 (2702.75-84) and B-0701 (07.7584) have been shown to inhibit the differentiation of cytotoxic $\mathrm{T}$ cells in vitro in a non-allelerestricted fashion (i.e., the effect of the peptides is the same, regardless of donor haplotype or target specificity) $(4,5)$. In addition to their effect on $\mathrm{T}$ cells, these peptides also decreased natural killer (NK) cell-mediated cytotoxicity, suggesting that their mechanism of action is independent of the indirect presentation that has been shown to be responsible for the biological activity of other allele-specific HLA-derived peptides. Peptides 2702.75-84 and 07.75-84 prolonged allograft survival in rodents and induced tolerance when administered in conjunction with subtherapeutic doses of cyclosporin A (CsA) (6-9). We have recently shown that these peptides' immunomodulatory activity is correlated with peptidemediated modulation of the activity of heme oxygenase 1 (HO-1), also called HSP32 (10). Novel peptides with enhanced immunomodulatory activity have been developed by computer-assisted rational design based on in vivo data (11). These peptides have been shown to be efficient inhibitors of HO- 1 in vitro. In the present study, one of these peptides, RDP1258, was assessed for its ability to modulate immune responses in rats and to affect heterotopic heart graft survival. Peptide RDP1258 was found to prolong allograft survival significantly, and this prolonged survival was associated with enhanced expression of splenic HO-1. Moreover, allografts from treated recipients showed a significant decrease in the number of graft-infiltrating cells, particularly in the CD68/monocyte population; decreased expression of tumor necrosis factor $\alpha$ (TNF- $\alpha$ ) mRNA; and an increased level of inducible nitric oxide synthase (iNOS) mRNA. These results support the hypothesis that RDP1258-mediated immunomodulation involves HO-1 activity and monocyte/macrophage functions.

\section{Materials and Methods}

\section{Reagents}

Peptides were synthesized using F-moc chemistry, purified by HPLC, and shown to be $>90 \%$ homogeneous by analytical reverse phase HPLC (SynPep, Dublin, CA). The following peptides were used: 2702.75-84, RENLRIALRY; 07.75-84, RESLRNLRGY; and RDP1258, RNleNleNleRNleNleNleGY-CONH2, where Nle is norleucine. Metalloporphyrins, purchased from Porphyrin Products (Logan, UT), were dissolved in a small quantity of $0.2 \mathrm{M} \mathrm{NaOH}$, subsequently adjusted to $\mathrm{pH} 7.4$ with $1 \mathrm{M} \mathrm{HCl}$ and diluted in $0.85 \%$ $\mathrm{NaCl}$. The stock concentration of metalloporphyrins was $1 \mathrm{mg} / \mathrm{ml}$.

\section{Antibodies}

The following mouse monoclonal antibodies (MAbs) were used to phenotype rat leukocytes: OX19 (anti-CD5, T cells), EDl (recognizing most tissue macrophages, and monocytes, granulocytes, and dendritic cells), MRC OX33 (antiCD45 isoform present on B cells only), MRC OX1 (anti-CD45), MRC OX8 (anti-CD8), and W3/25 (anti-CD4). All these MAbs were purchased from ECACC. The mouse anti-rat MAb 3.2.3, reacting with NK cells, was generously donated by W. H. Chambers (Pittsburgh, PA). For HO-l staining, a polyclonal rabbit anti-rat $\mathrm{HO}-1$ antibody was used (OSA100 Sress-gen), followed by a peroxidase-conjugated chicken anti-rabbit IgG (Vector Laboratories).

\section{HO-1 Enzyme Assay}

To determine HO activity in tissues, rat spleen samples were homogenized on ice in a Tris- $\mathrm{HCl}$ lysis buffer $(\mathrm{pH} 7.4)$ containing $0.5 \%$ Triton $\mathrm{X}-100$ and protease inhibitors. Samples were frozen in small aliquots until use. Spleen homogenate $(100 \mu \mathrm{l})$ was mixed with $0.8 \mathrm{mM}$ NADPH, $0.8 \mathrm{mM}$ glucose-6-phosphate, $1.0 \mathrm{U}$ G-6-P dehydrogenase, $1 \mathrm{mM} \mathrm{MgCl}_{2}$, and $10 \mu \mathrm{l}$ purified rat liver biliverdin reductase at $4^{\circ} \mathrm{C}$. The reaction was initiated by the addition of hemin (final concentration, $0.25 \mathrm{mM}$ ). The reaction mixture was incubated at $37^{\circ} \mathrm{C}$ in the dark for $15 \mathrm{~min}$. At the end of the incubation period, any insoluble material was removed by centrifugation and supernatants were analyzed for bilirubin concentration by measuring the difference in absorbance at 460 and $530 \mathrm{~nm}$. An extinction coefficient of $40 \mathrm{mM}^{-1} \mathrm{~cm}^{-1}$ at A 460-530 was used to calculate the amount of bilirubin formed. Controls included spleen samples in the absence of the NADPH generating system, and all the ingredients of the reaction mixture in the absence of spleen homogenates. Biliverdin reductase was purified from rat liver using the method described by Kutty and Maines (12).

\section{Heart Allograft Transplantation}

Eight- to 12-week-old male Lewis.lW (RT1. ${ }^{\mathrm{u}}$ ) and Lewis.1A $\left(\mathrm{RTl} .^{\mathrm{a}}\right)$ rats served as donors and 
recipients of heart allografts, respectively. These congenic strains were obtained from the Centre d'Elevage Janvier (Le Genest-Saint-Isle, France). Heterotopic heart grafts were performed using Ono and Lindsey's technique (13). The grafts were evaluated daily for function by palpation through the abdominal wall. Lewis. 1 A recipients rejected Lewis. $1 \mathrm{~W}$ heart allografts in $6 \pm 0.7$ days.

\section{Immunohistology}

Tissue samples for immunohistology were embedded in Tissue Tek (OCT compound), snap frozen in liquid nitrogen immediately after harvesting, and stored at $-70^{\circ} \mathrm{C}$ until used. Five micrometer cryostat sections were cut at $-20^{\circ} \mathrm{C}$, air dried, fixed in acetone for $10 \mathrm{~min}$ at room temperature, and stored at $-20^{\circ} \mathrm{C}$. Tissue sections were labeled using a three-step indirect immunoperoxidase technique (6). Negative controls were performed, omitting the first antibody.

\section{Quantitative Analysis of Cellular Infiltrate}

The area of each immunoperoxydase-labeled tissue section infiltrated by leukocytes of a particular phenotype was determined by morphometric analysis using the point-counting technique (6). With the aid of a 121 intersection-bearing square grid in the eyepiece, sections were examined at a magnification of $400 \times$ by two observers. For each of 15 adjacent high-power fields, the number of positively stained cells superimposed by an intersection was counted and the percentage area of each section occupied by cells of a particular phenotype was calculated as follows: [(number of positive cells under grid intersections) /(total number of grid intersections)] $\times$ 100.

Sera

Blood samples were obtained by heart puncture under ether anesthesia and clotted at $37^{\circ} \mathrm{C}$. Sera were heat inactivated at $56^{\circ} \mathrm{C}$ for $30 \mathrm{~min}$, and stored at $-20^{\circ} \mathrm{C}$.

\section{Preparation of Cell Suspensions}

Infiltrating mononuclear cells were mechanically harvested from heart allografts without the use of enzymes, as previously described (6). Briefly, heart grafts were finely minced and gently pressed through a stainless steel mesh, filtered twice, and layered on a Ficoll-Hypaque gradient. Splenocytes were flushed by multiple intrasplenic injections of phosphate-buffered saline (PBS) and mononuclear cells were obtained after a Ficoll-Hypaque gradient density.

\section{Detection of Anti-Donor Alloantibodies}

Concanavalin-A (Con A) blasts were prepared from LEW. $1 W$. Con-A splenocytes, $1 \times 10^{5}$ in 30 $\mu \mathrm{l}$, were incubated with $30 \mu$ l diluted sera (1:2, $1: 4,1: 8$ and $1: 16$ ) for $45 \mathrm{~min}$ at $4^{\circ} \mathrm{C}$, and washed twice in PBS containing $0.5 \%$ bovine serum albumin (BSA) (Sigma) and $0.02 \%$ sodium azide (Az) (PBS-BSA-Az). To stain for IgG alloantibodies, washed cells were made to react with $30 \mu \mathrm{l}$ of PBS-BSA-Az containing fluorescein isothiocyanate (FITC) conjugated $F\left(a^{\prime}\right)^{2}$ goat antibody specific for the Fc portion of rat IgG, (Jackson Immunoresearch Labs, West Grove, PA) for 30 $\min$ at $4^{\circ} \mathrm{C}$. After two additional washes, cells were fixed in $1 \%$ neutral buffered formalin and analyzed on a FACS calibur (Becton-Dickinson, Mountain View, CA).

\section{Cytotoxic Assays}

Graft infiltrating cells from treated and untreated recipients were tested for alloantigen-specific and nonspecific cytotoxicity using a standard 6 $\mathrm{hr}{ }^{51} \mathrm{Cr}$-release assay as described elsewhere (6). Allo-specific cytotoxicity was assessed using Con-A blasts from LEW.1W (RT1 ${ }^{\mathrm{u}}$ targets) and LEW.1A (RT1 ${ }^{\mathrm{a}}$ targets). Spontaneous cytotoxicity was assessed using the NK-susceptible YAC cell line. Specific ${ }^{51} \mathrm{Cr}$-release was calculated according to the formula $100 \times$ (experimental release - spontaneous release)/(maximum release - spontaneous release). Data are shown as the mean of triplicate determinations of 25:1 ratio, spontaneous release being $<20 \%$ of maximum release in all experiments.

\section{Competitive Quantitative PCR}

The sequences of the oligonucleotides are listed in Table 1. Oligonucleotides designated as X.Cons encompass the X.5' primer, four bases of the $X$ cDNA sequence, followed by a deletion of four bases and ending with the corresponding sequence of the X cDNA sequence (14). Total RNA from heart allografts was purified in a cesium chloride gradient (15). Ten micrograms was reverse transcribed, using the Boehringer cDNA synthesis kit, and diluted in a final volume of 100 
Table 1. Oligonucleotide sequences

\begin{tabular}{ll}
\hline Primers & \multicolumn{1}{c}{ Sequences $\left(\mathbf{5}^{\prime} \mathbf{-} \mathbf{3}^{\prime}\right.$ ) } \\
\hline iNOS-5' & ACTCAAGTTCAGCTTGGCGG \\
iNOS-3' & GGAGTGTCAG TGGCTTCCAG \\
iNOS RO & CATGCGGCCT CCTTTGAGC \\
TNF- $\boldsymbol{\alpha}-5^{\prime}$ & CTACTGCTTCAGCTCCACAG \\
TNF- $\boldsymbol{\alpha}-$ - $^{\prime}$ & GACCCGTAGGGCGATTACAG \\
TNF- $\boldsymbol{\alpha}$-RO & GCTTCCCAACGCTGGGTCC \\
\hline
\end{tabular}

$\mu l$. Standard constructions were performed essentially as previously described (14). Quantification of transcript $\mathrm{X}$ was performed as previously described (14). Briefly, a constant amount of cDNA corresponding to the reverse transcription of $50 \mathrm{ng}$ of total RNA was mixed with $10^{6}$, $10^{5}, 10^{4}, 10^{3}, 10^{2}$, or 0 copies of the $\mathrm{X}$ standard, and then amplified to saturation. This was followed by a dye-labeled oligonucleotide elongation (runoff reaction), and the runoff reaction products were electrophoresed for $7 \mathrm{hr}$ using an Applied Biosystem 373A DNA Sequencer. The Immunoscope ${ }^{\circledR}$ software was specially devised to measure both the length of each DNA peak detected (with a precision of $<0.2$ nucleotide) and its area (with a precision of $<5 \%$ ) (14).

\section{Statistical Analysis}

To compare the number of mRNA copies and the percentage of antibody labeling in each of the two experimental groups, the Student's $t$-test was performed, and $p<0.05$ was considered significant. Allograft survival times were compared using the Kaplan-Meier test.

\section{Results}

Peptide RDP1258-Mediated Modulation of Rat HO-1 Activity

Recently, peptides $2702.75-84,07.75-84$ and derivatives thereof have been shown to inhibit HO- 1 activity in vitro (10). The rational design of peptide RDP1258 was based solely on in vivo data (prolongation of heart allograft survival) (11). To determine whether peptide RDP1258 interacted with rat HO-1, enzyme activity in spleen homogenates was measured in vitro in the presence of increasing concentrations of pep-

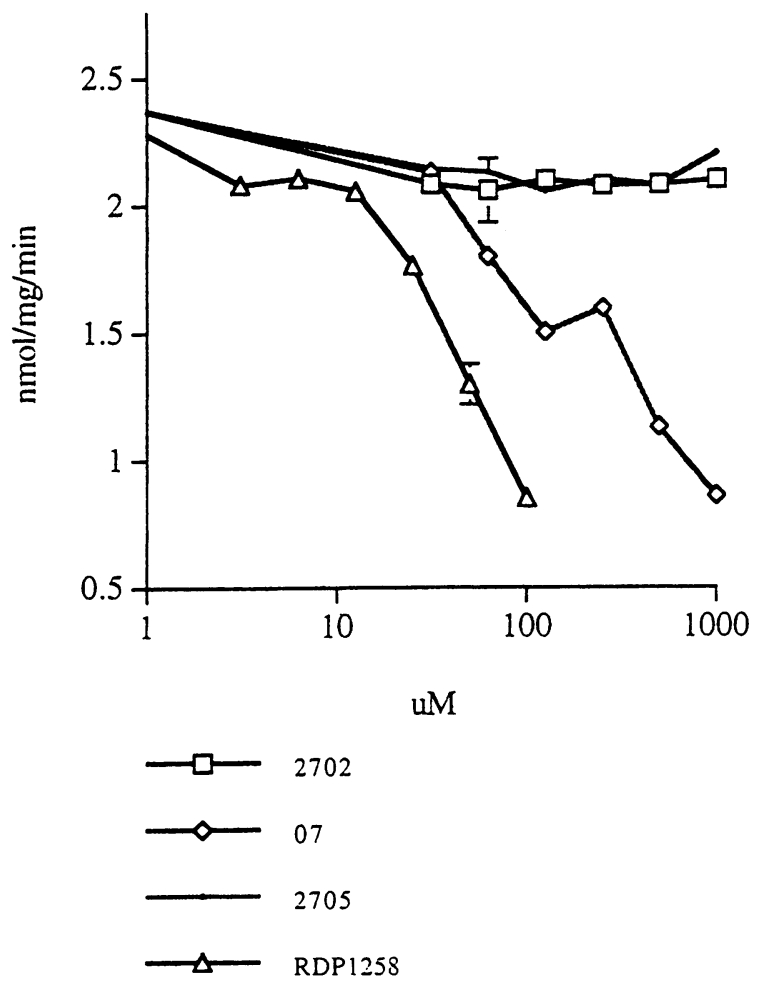

Fig. 1. Effect of peptide on in vitro HO activity. The activity of heme oxygenase in a spleen cell extract was measured in the presence of increasing amounts of peptide 2702.75-84 (squares), 07.75-84 (diamonds), 2705.75-84 (line), and RDP1258 (triangles). Enzyme activity is expressed as nmol bilirubin formed $/ \mathrm{mg}$ of protein $/ \mathrm{min}$.

tide (Fig. 1). Half-maximal inhibition of HO-1 activity by peptide $07.75-84\left(\mathrm{IC}_{50}\right)$ was observed at $200 \mu \mathrm{M}$. Peptide RDP1258 appeared to be more effective, the observed $\mathrm{IC}_{50}$ being $20 \mu \mathrm{M}$. Peptide 2702.75-84 had no effect on rat HO-1 activity, which is consistent with the observation that it had no effect on rat allograft survival $(6,16)$. In contrast, peptide $07.75-84$, which was shown to be effective in rats but not in mice, inhibited rat HO-1 activity $(6,16)$. Moreover, the results show that in vitro, RDP1258 peptide inhibited HO-l activity in a dose-dependent fashion.

It is well established that inhibition of HO-1 in vivo results in a rapid up-regulation of HO-1 production (17-19). The effect of peptide RDP1 258 on rat HO-1 was evaluated by measuring splenic HO-1 activity at various time points following administration of the peptide (Fig. 2). Injection of $0.5,1.0$, and $2.0 \mathrm{mg} / \mathrm{kg}$ resulted in increases of $22 \%, 66 \%$, and $45 \%$, respectively, in splenic HO-l activity $24 \mathrm{hr}$ after administra- 


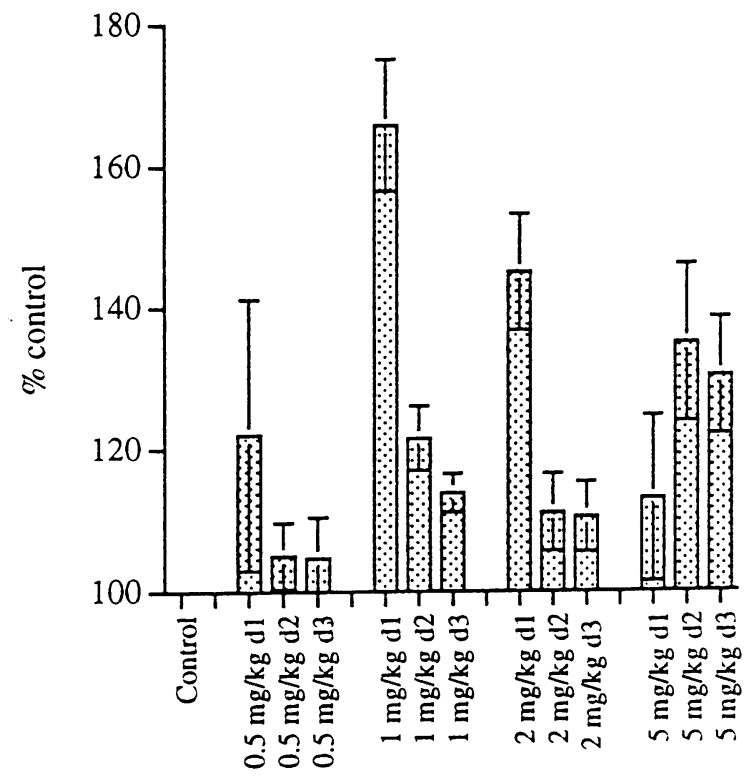

Fig. 2. Effect of peptide on splenic HO activity after in vivo treatment. Splenic $\mathrm{HO}$ activity was measured 24, 48, and $72 \mathrm{hr}$ following injection of the indicated amounts of peptide RDP1258. HO activity in peptide-treated animals $(n=3)$ was compared to mannitol-treated animals $(n=3)$ and is expressed as \% of control. HO activity in manitoltreated control animals was $3.081 \pm 0.051 \mathrm{nmol} /$ $\mathrm{mg} / \mathrm{min}$.

tion; this activity then declined to almost normal levels within the next $24 \mathrm{hr}$. Following the injection of $5 \mathrm{mg} / \mathrm{kg}$, the increase observed after 24 hr was $13 \%$. After 48 and $72 \mathrm{hr}$, increases of $35 \%$ and $30 \%$, respectively were observed. This delayed but sustained increase in HO-1 activity may be due to the prolonged continuing pres- ence of peptide RDP1258 following injection of this high dose $(5 \mathrm{mg} / \mathrm{kg})$.

The expression of splenic HO-1 was also evaluated in allograft recipients by immunohistochemistry. Spleens from untreated and RDP1258-treated allograft recipients (four animals per group) were removed 5 days after transplantation and labeled with anti-HO-1 polyclonal antibody (Fig. 3). Spleens from untreated recipients (Fig. 3A) showed almost no staining for HO-1 protein. In spleens from RDP1258treated recipients (Fig. 3B), the $\mathrm{HO}-1$ staining was intense in particular in the "marginal" zone of the spleen, which contains mostly monocytes and macrophages. We also analyzed the expression of HO-1 protein in heart allografts by immunoperoxidase staining. There is an increased expression of $\mathrm{HO}-1$ in allografts compared to naive heart, but we did not find any significant difference between allografts from both groups (data not shown).

\section{Prolonged Allograft Survival following Peptide RDP1258 Therapy}

The effect of peptide RDP1258 therapy on allograft survival was investigated in LEW.1A recipients of LEW.1W heart allografts. Recipients were treated before transplantation with different doses of the peptide. Heart allografts in untreated recipients were rejected in $6.6 \pm 0.6$ days (Fig. 4 and Table 2). Peptide RDP1258 therapy at $1 \mathrm{mg} / \mathrm{kg}$ on days -7 and -1 significantly prolonged allograft survival $(2 / 14>100$ days and $12 / 1416.2 \pm 1.7$ days vs. $6.6 \pm 0.6$ in the untreated group; $p \leq 0.001$ ). No further effect was observed when the dose was increased to 5

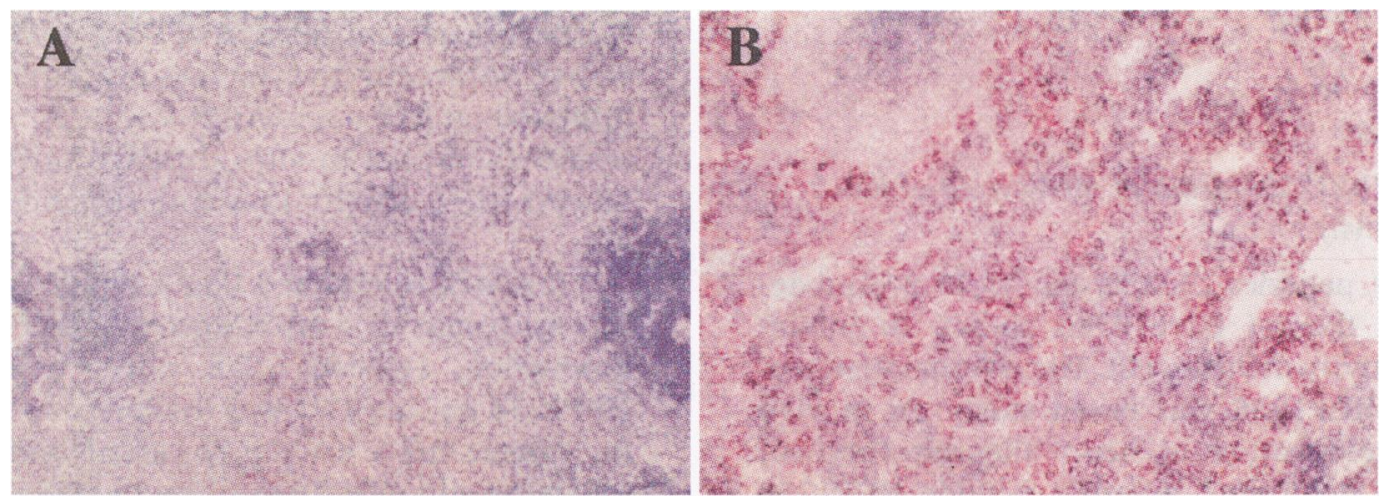

Fig. 3. HO-1 protein expression in spleen of allograft recipients. Immunostaining with an anti-HO- 1 -specific polyclonal antibody in spleen from untreated (A, 20× amplification) and RDP1258-treated (B, 20× amplification) allograft recipients 5 days after transplantation. 


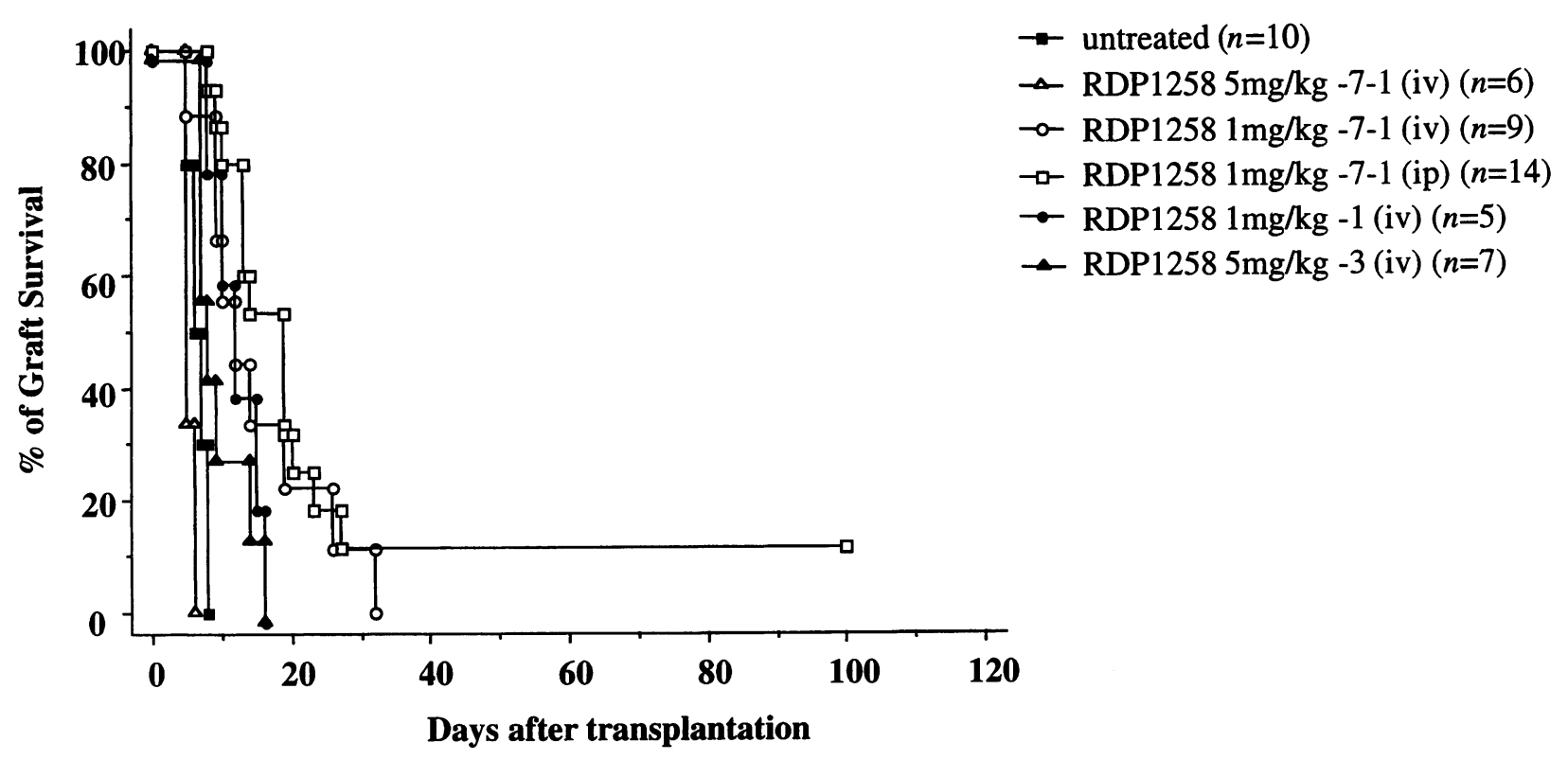

Fig. 4. Allograft survival after RDP1258 therapy. Kaplan-Meier depiction of heart allograft survival in rats receiving RDP1258 peptide therapy.

$\mathrm{mg} / \mathrm{kg}$ on days -7 and -1 . Interestingly, when the peptide was injected on day -3 at $5 \mathrm{mg} / \mathrm{kg}$, there was a small but significant $(p<0.009)$ prolongation of allograft survival compared to the effect of the same dose given on days -7 and -1 (Table 3). These results are in agreement with the effect (dose and timing) of peptide therapy in HO-1 activity (Fig. 2). A comparison of intravenous (IV) and intraperitoneal (IP) administration suggested that IP administration is as effective as IV administration (in the IP group $2 / 14>100$ days and in $12 / 14$ the mean allograft

Table 2. IgG alloantibody production in sera of allograft recipients 5 and 7 days after transplantation

\begin{tabular}{lcc}
\hline & \multicolumn{2}{c}{ IgG } \\
\cline { 2 - 3 } & Day 5 & Day 7 \\
\hline Untreated $(n=4)$ & $142 \pm 32$ & $185 \pm 0.5$ \\
RDP1258-treated $(n=4)$ & $156 \pm 28$ & $225 \pm 2.5$
\end{tabular}

Sera samples obtained from untreated and RDP1258treated allograft recipients at 5 and 7 days after transplantation were tested for IgG anti-donor specific alloantibody production against donor cells (see Materials and Methods). Results are expressed as the mean of channel fluorescence of four samples per group. survival was $16.2 \pm 1.7$ days vs. $15.1 \pm 2.9$ in the IV group).

ZnPP Abrogates the Effect on Allograft Survival of Peptide RDP1258 Therapy

Zinc-protoporphyrin (ZnPP) is a well-known inhibitor of HO-1 activity (20-23). To test if the effect of RDP1258 peptide was mediated in part by an increase in HO-l activity, the administration of ZnPP was investigated to see whether it inhibits the effect of RDP1258 treatment. Recipients were treated with RDP 1258 on days -7 and $-1 \mathrm{IP}$ at $1 \mathrm{mg} / \mathrm{kg}$ and the day of the graft they were treated with $\mathrm{ZnPP}$ at $10 \mathrm{mg} / \mathrm{Kg}$ subcutaneously (SC). As shown in Table 3, recipients treated with $\mathrm{ZnPP}$ rejected their graft in 7.2 \pm 0.8 days, suggesting that the effect of RDP1258 therapy was cancelled by ZnPP treatment $(p<0.02)$.

\section{Prolonged Allograft Survival following Cobalt- protoporphyrin Therapy}

Cobalt-protoporphyrin (CoPP) is a known inhibitor of HO-1 (17-19). The administration of CoPP was therefore investigated to see whether it might mimic some of the peptide's effect. It was shown to result in up-regulation of HO-1 similar to that observed with peptide RDP1258. In addition, CoPP has been shown to prolong heart allograft survival in mice (24). We therefore studied its effect on allograft survival in rats. 
Table 3. RDP1258 peptide effects on allograft survival

\begin{tabular}{|c|c|c|}
\hline Treatment & Graft survival & Mean \pm SEM \\
\hline No treatment & $5,5,6,6,6,7,7,8,8,8$ & $6.6 \pm 0.6$ \\
\hline RDP1258 $5 \mathrm{mg} / \mathrm{kg}$ i.v. day $-7,-1$ & $5,5,5,5,6,6$ & $5.3 \pm 0.2$ \\
\hline RDP1258 $5 \mathrm{mg} / \mathrm{kg}$ i.v. day -3 & $7,7,7,8,9,14,16$ & $9.7 \pm 1.4^{a}$ \\
\hline RDP1258 $1 \mathrm{mg} / \mathrm{kg}$ i.v. day $-7,-1$ & $5,9,9,10,12,14,19,26,32$ & $15.1 \pm 2.9^{b}$ \\
\hline RDP1258 $1 \mathrm{mg} / \mathrm{kg}$ i.v. day -1 & $8,10,12,15,16$ & $12.2 \pm 1$ \\
\hline RDP1258 $1 \mathrm{mg} / \mathrm{kg}$ i.p. day $-7,-1$ & $8,9,10,13,13,14,19,19,19,20,23,27,>100,>100$ & $16.2 \pm 1.7^{c}$ \\
\hline $\begin{array}{l}\text { RDP } 12581 \mathrm{mg} / \mathrm{kg} \text { i.p. day }-7,-1 \\
\text { and ZnPP } 20 \mathrm{mg} / \mathrm{kg} \text { s.c. day } 0\end{array}$ & $6,6,6,6,8,11$ & $7.2 \pm 0.8^{d}$ \\
\hline ZnPP 20 mg/kg s.c. day 0 & $7,8,13,14$ & $10.5 \pm 1.8$ \\
\hline \multicolumn{3}{|c|}{$\begin{array}{l}a_{p}<0.009 \text { compared to RDP1258 } 5 \mathrm{mg} / \mathrm{kg} \mathrm{IV} \mathrm{day}-7,-1 \text { group. } \\
b p<0.0035 \text { compared to untreated group. } \\
c_{p}<0.0008 \text { compared to untreated group, taking out the two }>100 \text { days from the analyses. } \\
d_{p}<0.02 \text { compared to RDP1258 } 1 \mathrm{mg} / \mathrm{kg} \mathrm{IP} \mathrm{day}-7,-1 \text { group. }\end{array}$} \\
\hline
\end{tabular}

Recipients were treated with either 5 or 2.5 $\mathrm{mg} / \mathrm{kg}$ of CoPP (SC or IP) 1 day before transplantation. As shown in Figure 5, administration of CoPP resulted in a significantly prolonged heart allograft survival (mean allograft survival $13 \pm$ 2.3 days vs. $6.6 \pm 0.6$ days; $p<0.02$ ), though less than that observed with RDP1258.

\section{Analysis of Graft-Infiltrating Cells}

Graft-infiltrating cells (GIC) were analyzed 5 days after transplantation. We have previously shown that cellular infiltrate in LEW.1W heart allografts peaks on day 5 (14). Four animals in each group were therefore studied at this time

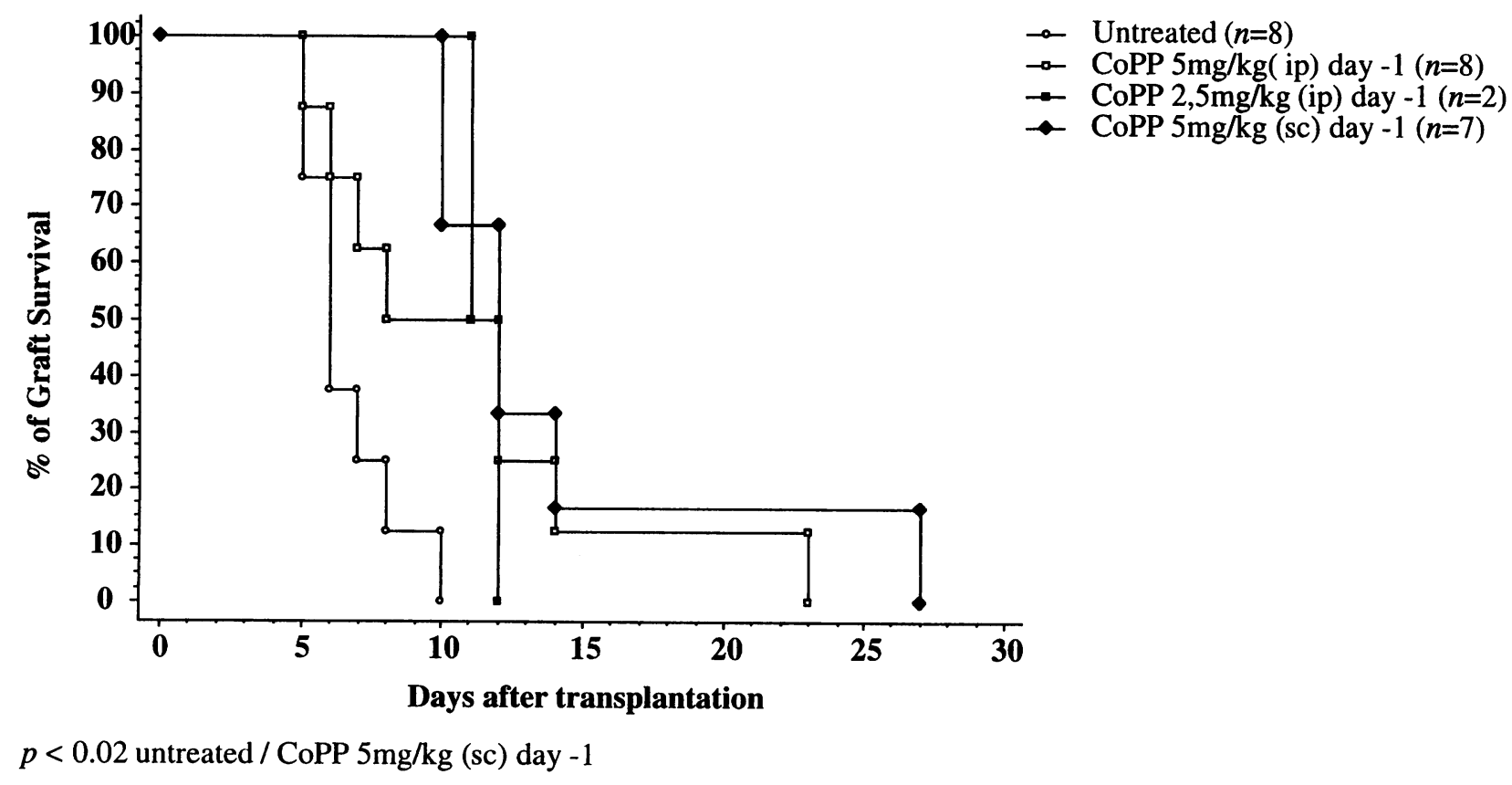

Fig. 5. Allograft survival after CoPP therapy. Kaplan-Meier depiction of heart allograft survival in rats receiving CoPP therapy. 
A

B

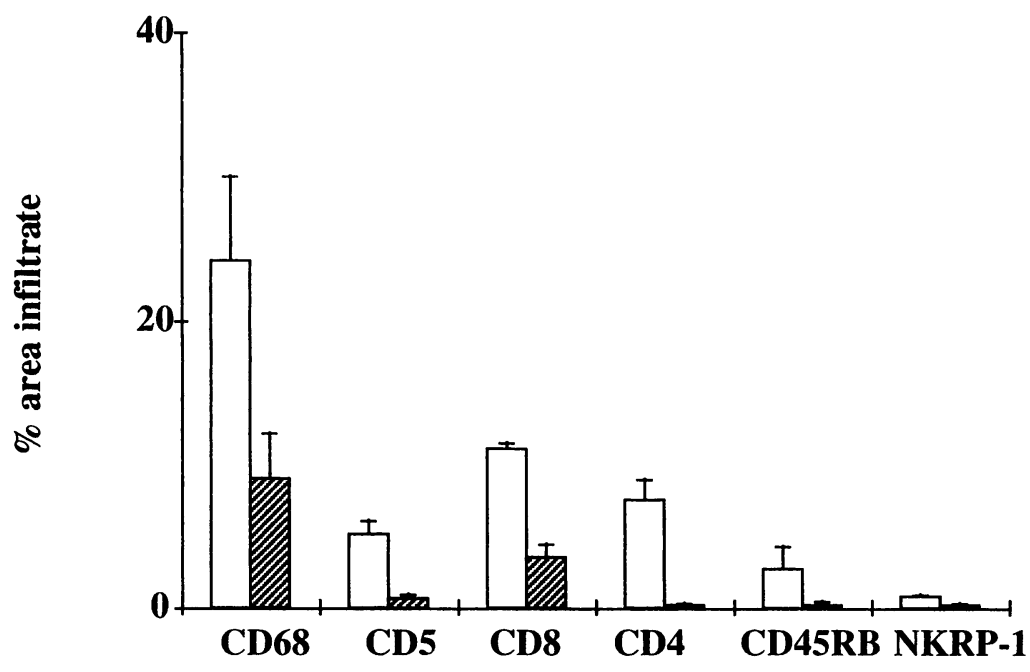

$\square$ Untreated $(n=4)$

RDP1258-treated $(n=4)$
Fig. 6. Immunohistochemical analysis of graft infiltrating cells. (A) Sections from heart allografts removed from untreated or RDP1258treated recipients 5 days after transplantation were stained with antiCD45 specific monoclonal antibodies (OXl and OX30). A quantitative analysis of graft infiltrating cells from untreated (open bar) and RDP1258 treated recipients (stippled bar) (mean $\pm \mathrm{SD}, n=4$ ) is shown; ${ }^{*} p<$ 0.01 . (B) Cryostat sections were stained with specific anti-rat monoclonal antibodies ED1 (CD68); OX19 (CD5, pan-T); W3/25 (CD4); OX8 (CD8); OX33 (CD45RB, B cells); 3.2 .3 (NKRP-1) and quantified as described in Materials and Methods. The percentage of area infiltrated (mean \pm $\mathrm{SD}, n=4$ ) in untreated (open bars) and RDP1258-treated (stippled bars) is shown; ${ }^{*} p<0.01$. point; a quantitative analysis of cryostat sections is shown in Figure 6. A comparison of grafts from untreated and peptide treated recipients revealed a highly significant reduction in the number of GIC, labeled with OXI and OX30 MAbs (antileukocyte common antigen CD45), (32.7 $\pm 9 \%$ vs. $14.8 \pm 4 \% ; p<0.01$ ) (Fig. $6 \mathrm{~A}$ ). As shown in Figure 6B, most GIC were CD68 positive (EDl present in macrophages, monocytes, granulocytes, and dendritic cells), but T, B, and NK cells were also present. $T$ cells were analyzed with OX19 (CD5, pan T lymphocytes), OX8 (CD8 $\alpha \beta$ and $\mathrm{CD} 8 \alpha \alpha$ ), and $\mathrm{W} 3 / 25$ (CD4); B cells with OX33 (CD45RA); and NK cells with MAb 3.2.3 (NKRP1). Numbers of all cell subsets studied were significantly reduced in grafts from peptide RDP1258-treated recipients (Fig. 6). The median of the percentage of area labeled with MAb CD68 was $24.2 \pm 6 \%$ in untreated recipients vs. $8.9 \pm$ $3 \%$ in RDP1258-treated recipients $(p<0.01)$; with MAb OX19, $5.2 \pm 1 \%$ vs. $0.6 \pm 0.4 \%(p<$ $0.0002)$; with $\mathrm{MAb}$ OX8, $11 \pm 0.6 \%$ vs. $3.5 \pm$
$1 \%(p<0.001)$; with MAb W3/25, $7.5 \pm 1 \%$ vs. $0.2 \pm 0.1 \%(p<0.0001)$; with MAb OX33, $2.7 \pm$ $1.6 \%$ vs. $0.2 \pm 0.1 \%(p<0.01)$; and with MAb 3.2.3, $0.8 \pm 0.2 \%$ vs. $0.1 \pm 0.2 \%(p<0.01)$.

\section{Analysis of mRNA Expression in Allografts}

To further assess the functional activity of GIC in allografts, we analyzed the expression of TNF- $\alpha$, IFN- $\gamma$, IL-10, and iNOS. Messenger RNA levels were measured by competitive RT-PCR using RNA isolated from allografts harvested on day 5 after transplantation. Transcript numbers were standardized with respect to the expression of hypoxanthin phosphoribosyl transferase (HPRT) (Fig. 7). A comparison of iNOS mRNA levels in the grafts of four untreated and four peptidetreated recipients showed a significant increase in iNOS mRNA levels $(0.25 \pm 0.09$ copies in untreated vs. $0.55 \pm 0.09$ copies in RPD 1258 treated-recipients; $p<0.05$ ). In contrast, TNF- $\alpha$ mRNA levels were significantly reduced follow- 


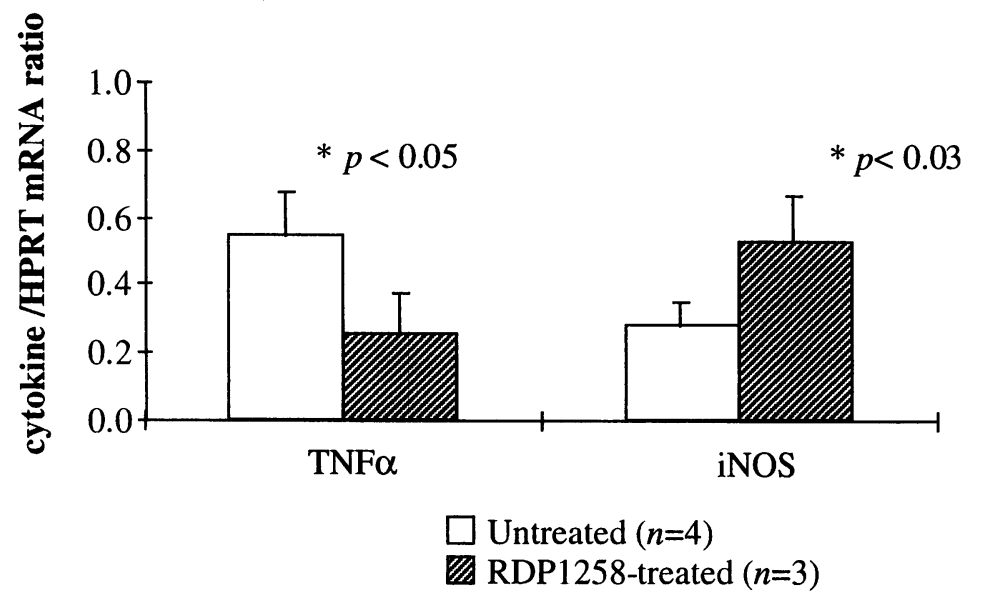

Fig. 7. Quantitative analysis of TNF- $\alpha$ and iNOS mRNA levels. Graft RNA was extracted from untreated (open bars) and RDP1258-treated (stippled bars) recipients 5 days after transplantation. RNA was reverse transcribed and analyzed by quantitative PCR. Results are expressed as mean \pm SD of the number of cytokine transcripts per number of HPRT transcripts. ing peptide therapy $(0.59 \pm 0.05$ copies in untreated vs. $0.28 \pm 0.11$ copies in RPD 1258 treated-recipients; $p<0.03$ ). Finally, analysis of IFN- $\gamma$ (IFN- $\gamma /$ HPRT ratio: untreated $0.027 \pm$ $0.011, n=4$; RDP1258-treated $0.042 \pm 0.019$, $n=4$ ) and IL-10, (IL-10/HPRT ratio: untreated $0.16 \pm 0.05, n=4 ;$ RDP1258-treated $0.20 \pm$ $0.09, n=4$ ) revealed no significant differences in expression between the two experimental groups.

\section{Cytotoxic Activity of GIC}

We have previously (6) evaluated the peptide 07.75-84, derived from the al helix of HLA B7, in the LEW.1W/LEW.1A allograft model. Peptide 07.75-84 therapy prolonged heart allograft survival and reduced the cytotoxic activity of GIC (6). GIC isolated from RDP1258-treated recipients 5 days after transplantation were therefore tested both for specific anti-donor and nonspecific (NK cell-mediated) cytotoxicity in three independent experiments. In no instance was a reduction in GIC-mediated cytotoxicity observed following peptide RDP1258 therapy (Table 4).

\section{Analysis of Alloantibody Production}

Alloantibody production was analyzed on days 5 and 7 after transplantation. Antibody binding to donor type conA-stimulated donor cells expressing donor class I and II MHC antigens was measured using a serial dilution of decomplemented sera. IgG alloantibodies were evaluated with sera from four animals per group. No differences were observed in IgG antibody titers with sera from untreated or peptide-treated animals (Table 2).

\section{Discussion}

In this study, we evaluated the effect of a rationally designed immunomodulatory peptide on allograft rejection in a rat model. Peptide RDP1258 was shown to inhibit rat HO-1 in vitro in a dose-dependent manner. In vivo, administration of peptide RDP1258 resulted in up-regulation of splenic HO activity similar to that described with other known inhibitors of HO-1, in particular, cobalt-protoporphyrin. Peptide treatment of allograft recipients before transplantation resulted in significantly prolonged graft survival, a decrease in the number of graft infiltrating cells, decreased expression of graft TNF- $\alpha$ mRNA, and increased iNOS mRNA levels. No effects on IgG alloantibody responses were observed.

Both peptides 2702.75-84 and 07.75-84 derived from HLA class I have been shown to modulate HO-1 activity (10). Peptide 2702.75-84 in-

Table 4. Anti-donor and nonspecific cytotoxic activity of graft-infiltrating cells

\begin{tabular}{lcc}
\hline & $\begin{array}{c}\text { Donor cells } \\
(\%)\end{array}$ & $\begin{array}{c}\text { YAC cells } \\
(\%)\end{array}$ \\
\hline Untreated $(n=3)$ & 22.8 & 15 \\
RDP1258 treated $(n=3)$ & 24 & 14 \\
\hline
\end{tabular}

Graft-infiltrating cells from treated and untreated recipients were tested for alloantigen-specific (donor cells) and nonspecific (YAC cell line) cytotoxicity. Data shown are the mean of triplicate determinations of 25:1 ratio, spontaneous release being $<20 \%$ of maximum release in all experiments. 
hibits $\mathrm{HO}$ in the mouse, but not in the rat, whereas peptide 07.75-84 inhibits HO more effectively in the rat than in the mouse. This difference fits with the well-documented $(8,16)$ specificity of the two peptides. Peptide 2702.75-84 has been shown to prolong allograft survival in mice but not in rats $(7,25,26)$, whereas peptide $07.75-84$ has been shown to prolong allograft survival in rats but not in mice $(6,9,27,28)$. Peptide RDP1258, the design of which was based on in vivo data (prolonged graft survival), is a more effective inhibitor of both rat and mouse HO, and appears to prolong graft survival in both rodent species. CoPP, a wellknown modulator of $\mathrm{HO}$, has also been shown to prolong allograft survival in mice (24) and rats (this report). Taken together, these data support the hypothesis that modulation of $\mathrm{HO}$ activity is involved in peptide-mediated prolongation of allograft survival.

It is well established that inhibition of $\mathrm{HO}$ in vivo results in the up-regulation of HO mRNA and protein levels (19). This may be to due to an increase in the concentration of intracellular heme, a toxic compound whose concentration has to be tightly controlled (19). Our peptide studies in mice are consistent with this observation (10). Administration of peptide into mice was shown to induce HO-1 gene transcription and HO-1 protein production. Depending on the half-life and potency of the administered HOinhibitor, up-regulation of HO- 1 in cells or animals is not necessarily associated with increased HO-1 activity. For example, administration of Zn-protoporphyrin, a very effective inhibitor of HO (21-23), resulted in up-regulation of HO-1 expression similar to the observations made with CoPP or peptide RDP1258. However, in contrast to CoPP and peptide RDP1258, injection of ZnPP resulted in a severe inhibition of $\mathrm{HO}$ activity in vivo. To further analyze the role of HO up-regulation in the in vivo effect of peptide, we treated the peptide-treated allograft recipients the day of transplantation with ZnPP in order to inhibit the HO activity. As shown in Table $3 \mathrm{ZnPP}$ therapy completely inhibited the effect of the peptide therapy, which suggests a role for HO in peptidemediated prolongation of allograft survival. Therefore, the up-regulation of HO-l expression following administration of a $\mathrm{HO}$ inhibitor was expected to be dependent on the potency of the compound as well as its pharmacokinetics. This is consistent with our observations in rats. Peptidemediated up-regulation of splenic HO expression and activity appeared to be dose dependent. The highest increase in splenic HO activity was observed 1 day after administration of $1 \mathrm{mg} / \mathrm{kg}$ peptide. A fivefold increase in dose caused no further increase in splenic HO activity; instead, the initial increase in enzyme activity was lowered, while increased enzyme activity appeared to last longer. This may be due to the partial inhibition of HO following injection of a large dose of enzyme inhibitor (peptide RDP1258). This observation may explain why a high dose of peptide RDP1258 $(5 \mathrm{mg} / \mathrm{kg}$ ) was less effective in prolonging graft survival than a dose of $1 \mathrm{mg} / \mathrm{kg}$ when administrated 1 day before transplantation and has a significant effect when administered 3 days before the graft (Table 3). In addition, it may explain why post-transplant therapy in our rat model was less effective than pretransplant therapy (data not shown). Furthermore, it could explain the differences observed with CoPP and peptide RDP1258. CoPP was shown to have a half-life of several days (24), whereas the halflife of peptide RDP1258 is expected to be short. Additional studies using various dose regimens will be necessary to clarify this issue.

Recently, up-regulation of HO-1 mRNA has also been described in renal allografts in rats 5 days after transplantation (29). Prominent expression of HO protein was observed in mononuclear cells infiltrating the renal allograft, $>80 \%$ of the cells being macrophages. In addition to up-regulation of HO-1 transcription, an increased expression of the iNOS gene was observed. A close linkage between iNOS and HO expression has also been described in other models $(19,30-32)$. These results are consistent with our observations in heart allograft recipients. Analysis of $\mathrm{HO}$ expression in spleen cells showed that the labeled cells were mostly macrophages and monocytes. Peptide therapy also caused increased HO expression in the spleen. Concomitantly, when iNOS expression in the graft was investigated, we found enhanced expression in peptide-treated recipients. In this context, it is interesting to note that a diet enriched in Larginine, the substrate of nitric oxide synthase, improves graft survival in immunosuppressed rat allograft recipients (33). Furthermore, it has been suggested that up-regulation of iNOS expression confers partial protection on the aortic allograft from developing allograft arteriosclerosis (34).

Up-regulation of $\mathrm{HO}$ activity in mice has been shown to inhibit inflammation and several immune effector functions $(24,35-39)$. In particular, up-regulation of $\mathrm{HO}-1$ is associated with 
decreased proliferation of lymphocytes and decreased production of TNF- $\alpha$, INF- $\gamma$, and IL- 10 . In contrast, production of IL-2 was not affected. Inhibition of HO-1, on the other hand, has been shown to stimulate the production of TNF- $\alpha$ and INF- $\gamma(24,39)$. Preliminary results of experiments with purified macrophages/monocytes and $\mathrm{T}$ cells from CoPP-treated animals indicated that the modulation of $\mathrm{T}$ cell effector functions is dependent on the presence of macrophages/ monotcytes (J. Woo, unpublished observations). These observations are consistent with our finding that peptide treatment resulted in a decreased expression of TNF- $\alpha$ in the graft.

Peptide therapy caused a reduction in the number of graft-infiltrating cells analyzed on day 5 post-transplantation. While it is unclear why peptide administration influenced graft infiltration, several possibilities can be envisioned. (i) Peptide-mediated immunosuppression may result in decreased production of cytokines and chemokines by graft-infiltrating lymphocytes. Consequently, less cells are routed into the allograft. (ii) Reduced cytokine production may result in decreased activation of endothelial cells. (iii) Peptide therapy may not only modulate immune effector functions but also directly activate endothelial cells. Further studies will be necessary to clarify these questions.

Peptide RDP1258 was shown to inhibit cytotoxic $\mathrm{T}$ and NK cells more effectively than peptide $07.75-84$. We have previously reported a reduction in $\mathrm{T}$ and NK cell-mediated cytotoxicity following peptide $07.75-84$ treatment of recipients $(6,16)$. However, analysis of GIC showed no difference in cytotoxic activity following peptide RDP 1258 therapy. This may be due to differences in pharmacokinetics and dose responses. As outlined above, such differences could have profound effects on modulation of HO activity in vivo. On the other hand, we cannot exclude the possibility that peptides $07.75-84$ and RDP1258 do not have identical biological activity and further studies will be necessary to clarify this issue.

Treatment with CoPP has also been shown to lower cell-mediated cytotoxicity (24). However, this effect required the administration of a large dose of CoPP $(20 \mathrm{mg} / \mathrm{kg})$ on 3 consecutive days, suggesting that it may be due not to up-regulation of HO activity but only to the modulation of other enzymes. Indeed, in addition to its effect on HO, Cobalt-protoporphyrin has been shown to modulate other heme enzymes, such as NOS and guanylate cyclase $(40,41)$. Therefore, high doses of CoPP may modulate several of the bio- chemical pathways influencing immune effector functions. While we cannot exclude the possibility that peptide RDP1258 may influence various different enzymes and pathways as well, our results support the hypothesis that its mechanism of action involves modulation of $\mathrm{HO}$ activity. In particular, up-regulation of HO-1, inhibition of the proliferation of lymphocytes, and reduced production of inflammatory cytokines may all be closely linked. How HO-1 up-regulation causes these effects remains unclear. However, all of the endproducts of heme degradation-biliverdin, bilirubin, and carbon monoxide-have been shown to modulate immune effector functions. Biliverdin has been shown to inhibit human complement (42) phytohemagglutinin-induced proliferation, IL-2 production, and antibody-dependent and -independent cell-mediated cytotoxicity $(43,44)$. Carbon monoxide, like NO, has been shown to stimulate the production of CGMP $(45,46)$. The secondary messenger, cGMP, is involved in cell growth arrest and TNF- $\alpha$ release by macrophages (47). In addition, cGMP is involved in the regulation of various protein kinases, phosphodiesterases, and ion channels (48-50). Carbon monoxide has also been shown to inhibit NO synthase models $(18,30-32)$. On the basis of these observations, multiple pathways of immunomodulation involving HO may be envisioned, the further characterization of which may lead to the development of novel strategies for modulation of the immune system.

\section{Acknowledgments}

The authors would like to thank Helga Smit, Valia Proust, and Claire Usal for their excellent work in heart allograft peptide therapy and animal care.

\section{References}

1. Parham P, Clayberger C, Zorn SL, Ludwig DS, Schoolnik GK, Krensky AM. (1987) Inhibition of alloreactive cytotoxic $\mathrm{T}$ lymphocytes by peptides from the alpha 2 domain of HLA-A2. Nature 325: 625-628.

2. Olson CA, Williams LC, McLaughlin-Taylor E, McMillan M. (1989) Creation of H-2 class I epitopes using synthetic peptides: recognition by alloreactive cytotoxic T lymphocytes. Proc. Natl. Acad. Sci. U.S.A. 86: 1031-1035.

3. Clayberger C, Parham P, Rothbard J, Ludwig DS, Schoolnik GK, Krensky AM. (1987) HLA-A2 peptides can regulate cytolysis by human allogeneic $\mathrm{T}$ lymphocytes. Nature 330: 763-765. 
4. Clayberger C, Krensky AM. (1995) Immunosuppressive peptides corresponding to MHC class I sequences. Curr. Opin. Immunol. 7: 644-648.

5. Clayberger C, Lyu SC, Pouletty P, Krensky AM. (1993) Peptides corresponding to T-cell receptorHLA contact regions inhibit class I-restricted immune responses. Transplant. Proc. 25: 477-478.

6. Cuturi MC, Josien R, Douillard P, et al. (1995) Prolongation of allogeneic heart graft survival in rats by administration of a peptide (a.a. 75-84) from the alpha 1 helix of the first domain of HLA-B7 01. Transplantation 59: 661-669.

7. Buelow R, Veyron P, Clayberger C, Pouletty $P$, Touraine JL. (1995) Prolongation of skin allograft survival in mice following administration of $\mathrm{AL}$ LOTRAP. Transplantation 59: 455-460.

8. Buelow R, Burlingham WJ, Clayberger C. (1995) Immunomodulation by soluble HLA class I. Transplantation 59: 649-654.

9. Nisco S, Vriens P, Hoyt G, et al. (1994) Induction of allograft tolerance in rats by an HLA class I-derived peptide and cyclosporine A. J. Immunol. 152: 3786-3792.

10. Iyer S, Woo J, Cornejo MC, et al. (1998) Characterization and biological significance of immunosuppressive peptide D2702.75-84(E $\rightarrow$ V) binding protein. Isolation of heme oxygenase-1. J. Biol. Chem. 273: 2692-2697.

11. Grassy G, Calas B, Yasri A, et al. (1998) In silico screening applied to the rational design of novel immunosuppressive compounds. Nat. Biotechnol. 16: $748-752$.

12. Kutty RK, Maines MD. (1981) Purification and characterization of biliverdin reductase from rat liver. J. Biol. Chem. 256: 3956.

13. Ono K, Lyndsey ES. (1969) Improved technique of heart transplantation in rats. J. Thorac. Cardiovasc. Surg. 57: 225-229.

14. Josien R, Pannetier C, Douillard P, et al. (1995) Graft infiltrating $\mathrm{T}$ helper cells, CD45RC phenotype, and Th1/Th2-related cytokines in donor specific transfusion-induced tolerance in adult rats. Transplantation 60: 1131-1139.

15. Chirgwin JJ, Przbyla AE, MacDonald RJ, Rutter WJ. (1979) Isolation of biologically active ribonucleic acid from sources enriched in ribonuclease. Biochemistry 18: 5294-5297.

16. Cuturi MC, Josien R, Douillard P, Giral M, Soulillou JP. (1996) Synthetic peptides derived from human MHC class I sequences delay allograft rejection in rodents and inhibit cell-mediated cytotoxicity in vivo and in vitro. Immunol. Rev. 154: 5-20.

17. Rosenberg DW, Drummond DS, Kappas A. (1982) The influence of organometals on heme metabolism. In vitro and in vivo studies with organotins. Mol. Pharmacol. 21: 150-158.

18. Maines M. (1984) New developments in the regulation of heme metabolism and their implications. CRC Crit. Rev. Toxicol. 12: 241-314.
19. Maines M. (1997) The heme oxygenase system: a regulator of second messenger gases. Annu. Rev. Pharmacol. Toxicol. 37: 517-554.

20. Seki T, Naruse $M$, Naruse $K$, et al. (1997) Roles of heme oxygenase/carbon monoxide system in genetically hypertensive rats. Biochem. Biophys. Res. Commun. 241: 574-578.

21. Ye J, Laychock SG. (1998) A protective role for heme oxygenase expression in pancreatic islets exposed to interleukin-1beta. Endocrinology 139: 4155-4163.

22. Rodgers PA, Seidman DS, Wei PL, Dennery PA, Stevenson DK. (1996) Duration of action and tissue distribution of zinc protoporphyrin in neonatal rats. Pediatr. Res. 39: 1041-1049.

23. Ny L, Alm P, Ekstrom P, Larsson B, Grundemar L, Andersson KE. (1996) Localization and activity of haem oxygenase and functional effects of carbon monoxide in the feline lower oesophageal sphincter. Br. J. Pharmacol. 118: 392-399.

24. Woo J, Iyer S, Cornejo $M$, et al. (1998) Stress protein induced immunosuppression: inhibition of cellular immune effector functions following overexpression of heme oxygenase (HSP32). Transplant. Immunol. 6: 84-93.

25. Woo J, Gao L, Cornejo MC, Buelow R. (1995) A synthetic dimeric HLA class I peptide inhibits $\mathrm{T}$ cell activity in vitro and prolongs allogeneic heart graft survival in a mouse model. Transplantation 60: 1156-1163.

26. Gao L, Woo J, Buelow R. (1996) Both L- and D-isomers of allotrap 2702 prolong cardiac allograft survival in mice. J. Heart Lung Transplant. 15: 78-87.

27. Murphy B, Kim KS, Buelow R, Sayegh MH, Hancock WW. (1997) Synthetic MHC class I peptide prolongs cardiac survival and attenuates transplant arteriosclerosis in the Lewis $\rightarrow$ Fischer 344 model of chronic allograft rejection. Transplantation 64: 14-19.

28. Hanaway MJ, Geissler EK, Wang J, Fechner JH, Jr, Buelow R, Knechtle SJ. (1996) Immunosuppressive effects of an HLA class I-derived peptide in a rat cardiac allograft model. Transplantation 61: 1222-1228.

29. Agarwal A, Younki K, Matas A, Alam J, Nath K. (1996) Gas generating systems in acute renal allograft rejection in the rat. Transplantation 61: 9398.

30. Durante W, Kroll M, Christodoulides N, Peyton K, Schafer A. (1997) Nitric oxide induces heme oxygenase-1 gene expression and carbon monoxide production in vascular smooth muscle cells. Circ. Res. 80: 557-564.

31. Kurata S, Matsumoto M, Ymashita U. (1996) Concomitant transcriptional activation of nictric oxide synthase and heme oxygenase genes during nitric oxide-mediated macrophage cytostasis. J. Biochem. 120: 49-52.

32. Takahashi K, Hara E, Ogawa K, Kimura D, Fujita 
H, Shibahara S. (1997) Possible implications of the induction of human heme oxygenase-1 by nitric oxide donors. J. Biochem. 121: 1161-1168.

33. Alexander J, Valente J, Greenberg N, et al. (1998) Dietary omega-3 and omega-9 fatty acids uniquely enhance allograft survival in cyclosporine-treated and donor-specific transfusion-treated rats. Transplantation 65: 1304-1309.

34. Shears L, Kawaharada N, Tzeng E, et al. (1997) Inducible nitric oxide synthase suppresses the development of allograft arteriosclerosis. J. Clin. Invest. 100: 2035-2042.

35. Willis D, Moore AR, Frederick R, Willoughby DA. (1996) Heme oxygenase: a novel target for the modulation of the inflammatory response. Nat. Med. 2: 87.

36. Otterbein L, Sylvester S, Choi A. (1995) Hemoglobin provides protection against lethal endotoxemia in rats: the role of heme oxygenase-1. Cell. Mol. Biol. 13: 595-601.

37. Vogt B, Shanley T, Croatt A, Alam J, Johnsons K, Nath K. (1996) Glomerular inflammation induces resistance to tubular injury in the rat. J. Clin. Invest. 98: 2139-2145.

38. Schwarzman $M$, Abraham N, Conners $M$, Dunn M, Levere R, Kappas A. (1997) Heme oxygenase induction with attenuation of experimentally induced corneal inflammation. Biochem. Pharmacol. 53: 1069-1075.

39. Novogrodsky A, Suthanthiran M, Stenzel K. (1989) Immune stimulatory properties of metalloporphyrins. J. Immunol. 143: 3981-3987.

40. Ignarro L, Ballot B, Wood K. (1984) Regulation of soluble guanylate cyclase activity by porphyrins and metalloporphyrins. J. Biol. Chem. 209: 62016207.

41. Wolff D, Naddelman R, Lubeskie A, Saks D. (1996) Inhibition of nitric oxide synthase isoforms by porphyrins. Arch. Biochem. Biophys. 333: 27-34.
42. Nakagami $T$, Toyomura $K$, Kinoshita $T$, Morisawa S. (1993) A beneficial role of bile pigments as an endogenous tissue protector: anti-complement effects of biliverdin and conjugated bilirubin. Biochem. Biophys. Acta 1158: 189-193.

43. Haga Y, Tempero A, Kay D, Zetterman R. (1996) Intracellular accumulation of unconjugated bilirubin inhibits phytohemagglutinin-induced proliferation and interleukin-2 production of human lymphocytes. Digest. Dis. Sci. 41: 1468-1474.

44. Haga Y, Tempero M, Zetterman R. (1996) Unconjugated bilirubin inhibits in vitro major histocompatibility complex-unrestricted cytotoxicity in human lymphocytes. Biochem. Biophys. Acta 1316: 29-34.

45. Verma A, Hirsch D, Glatt C, Ronnett G, Synder S. (1993) Carbon monoxide: a putative neural messenger. Science 259: 381-384.

46. Briine B, Ulrich V. (1987) Inhibition of platelet aggregation by carbon monoxide is mediated by activation of guanylate cyclase. Mol. Pharmacol. 32: 497-504.

47. Diaz J, Vara E, Garcia C, Villa N, Balibrea J. (1995) Evidence for a cyclic guanosine monophosphatedependent, carbon monoxide-mediated, signaling system in the regulation of TNF- $\alpha$ production by human pulmonary macrophages. Arch. Surg. 130: 1287-1293.

48. Vaandrager A, de Jonge H. (1996) Signalling by cGMP-dependent protein kinases. Mol. Cell. Biochem. 157: 23-30.

49. Lincoln $T$, Komalavilas $P$, Boerth N, MacMillanCrow L, Cornwell T. (1995) cGMP signalling through cAMP- and cGMP-dependent protein kinases. Adv. Pharmacol. 34: 305-322.

50. Finn J, Grunwald M, Yau K. (1996) Cyclic nucleotide-gated ion channels: an extended family with diverse functions. Annu. Rev. Physiol. 58: 395-426. 